\title{
Trusopplæringa sitt potensial i utvikling av menigheten
}

\author{
Av Hans Austnaberg og Erling Birkedal
}

Korleis kan trusopplaringa vera ein faktor i a utvikla menighetene i Den norske kyrkja? Dette er hovudspørsmålet $i$ artikkelen. Det empiriske materialet er etablert gjennom intervju med tilsette og soknerådsleiarar i seks menigheter. Analysen er strukturert etter fem ekklesiologiske dimensjonar over kva ein menighet bør vera og gjera. Hovudfunn er at trusopplaringa har ført til eit større «me» $i$ forståinga av kven som høyrer til menigheten, vekt på det teologiske innhaldet $i$ tiltaka, men òg ein ambivalens $i$ å relatera trusopplaringa til andre delar av arbeidet i menigheten. Ei utfordring for trusopploeringa er å bli meir fokusert på kva som er menigheten sitt oppdrag som sendt til verda, og vilje til stadig å vera i utvikling.

Nøkkelord: Trusopplæring, menighetsutvikling, stabssamarbeid, kateket/ menighetspedagog, prest

\footnotetext{
Hans Austnaberg, 1956, professor i praktisk teologi VID vitenskapelige høgskole, Haugtussavegen 6, 4344 Bryne, hans.austnaberg@vid.no

ERLING BirkedAL, 1954, forskar og prosjektleiar, Det teologiske menighetsfakultet, Likollen 39, 1481 Hagan, erling.birkedal@mf.no
}

\section{INTRODUKSJON}

Allereie etter fors $\emptyset \mathrm{ks}$ - og utviklingsfasen av trusopplæringsreforma (2004-08) observerte Hegstad, Selbekk og Aagedal at trusopplæringa i fleire av menighetene dei undersøkte, blei sett på som ein del av ein større menighetsutviklande prosess, ei moglegheit til å stimulera til endringar i den lokale kulturen i kyrkja. Dei hevdar at reforma kan «forstås som et utgangspunkt for og en impuls til det en kan kalle menighetsutvikling» (Hegstad, Aagedal, og Selbekk 2008:159). Vår forsking er ei empirisk undersøking av eit utsnitt av trusopplæringa. Med trusopplæring forstår me, i tråd med nasjonal plan (Kirkerådet 2010:4), Den norske kyrkja si oppfølging av døypte medlemmer mellom 0-18 år, synonymt med dåpsopplæring. Problemstillinga er å unders $\emptyset$ kja korleis trusopplæringa kan vera ein faktor i å utvikla menighetene i Den norske kyrkja. Menighetsutvikling kan forståast på ulike måtar. Det kan vera eit systematisk og målretta arbeid frå leiarar i menigheten for å nå dei måla ein ønskjer, eller det kan vera ei skildring av den utviklinga som faktisk skjer i menigheten (Birkedal 2015:157). Me har ikkje unders $\emptyset \mathrm{kt}$ korleis tiltak fungerer i praksis, og har heller ikkje materiale

Prismet - IKO-Forlaget 2017

Tilgjengelig på https://journals.uio.no/index.php/prismet Publisert under CC BY-NC 4.0. Fagfellevurdert

Årgang 68, hefte 3, s. 169-188 
på korleis barn og foreldre opplever trusopplæringa som menighetene står for. Det må derfor presiserast at det empiriske svaret på problemstillinga byggjer på informantane sine tankar, oppfatningar, ønsker og tidlegare erfaringar. Me tar derfor utgangspunkt i den første forståinga ovanfor og har i forskinga vår lagt fylgjande definisjon til grunn: Menighetsutvikling er «et målrettet arbeid for å sette menigheten bedre i stand til å være det den er kalt til å være og gjøre det den er kalt til å gjøre.» (Hegstad 2011:12).

Opplegget vidare i artikkelen er, etter ein presentasjon av materiale og metode, å gi ei teologisk forståing av menighet og menighetsutvikling som grunnlag for den vidare analysen av materialet med ei kortfatta påfølgande oppsummerande drøfting, for til slutt å svara på problemstillinga.

\section{Materiale og metode}

Denne artikkelen er ein del av eit større forskingsprosjekt. ${ }^{1}$ Me valde ut seks menigheter til den empiriske unders $\emptyset$ kinga, og det var særleg to kriterier som var avgjerande. Det første var at menighetene hadde fătt pengar frå Kirkerådet/trusopplæringsreforma, og slik var forplikta til å utvikla lokal plan for trusopplæring. Me forventa at dei i denne fasen var særleg merksame på utvikling og heilskap, sidan òg verktøyet for utvikling av lokal plan legg opp til at menighetene skal sjå trusopplæringa saman med andre delar av verksemda $\mathrm{i}$ menigheten (jf Kirkerådet 2010:45). Det andre kriteriet var at menighetene hadde erfaring med prosjektet «Menighetsutvikling i folkekirken» (MUV). ${ }^{2}$ Gjennom deltaking i dette hadde personane som var direkte involverte i MUV-prosjektet fått kjennskap til feltet menighetsutvikling og korleis ein kan arbeida med dette, i tillegg til noko erfaring med planarbeid og heilskapstenking. Me hadde ei førforståing og forventning om at desse menighetene skulle ha eit spesielt fokus på menighetsutvikling i prosessen med utvikling av lokal plan for trusopplæring. Det interessante var å sjå om det stemte. Viss ikkje desse menighetene såg trusopplæringa som menighetsutvikling, var det lite sannsynleg at andre menigheter, som ikkje tidlegare hadde arbeidd med systematisk menighetsutvikling, såg det slik.

Ein kan spørja seg om det er fornuftig å velja ut menigheter som allereie har arbeidd med menighetsutvikling. Det kan innvendast at dei unders $\emptyset$ kte menighetene då har spesielle føresetnader for å tenkja på trusopplæringa som menighetsutvikling, noko som me i undersøkinga vil finna ut av. Gjer me oss då skuldige i ein sirkelargumentasjon, noko som kan redusera validiteten $\mathrm{i}$ våre funn? Det interessante er at vi finn at trusopplæringa har blitt påverka av

1 Me er tre forskarar som har jobba saman i prosjektet og har skrive artiklar ut frå det same materialet. Sjå Austnaberg 2017, Birkedal 2017, Birkedal og Austnaberg 2017, Birkedal, Leganger-Krogstad og Aust $\neg$ naberg 2017, Leganger-Krogstad 2017.

2 Sjå http://www.mf.no/forskningphd/pagaende-prosjekter/muv, [24. august 2016]. 
menighetsutviklingsprosjektet i forskjellig grad frå menighet til menighet. Det tolkar me slik at eit menighetsutviklingsprosjekt ikkje nødvendigvis skaper spesielle føresetnader for heilskapstenking hos dei som arbeider med trusopplæring i menighetene. Mange forskjellige faktorar vil spela inn på dette. Mellom anna er utskifting av personar i stabane ei utfordring, ikkje berre for trusopplæringa, men òg i forhold til vidareføring av ei tenking om menighetsutvikling. Andre forskingsprosjekt med menigheter som ikkje tidlegare har erfaring med spesifikke menighetsutviklingsprosjekt, vil kunna utfylla våre funn.

Tre av menighetene ligg i eitt bisped $ø$ mme på Austlandet og tre på Vestlandet, nokre i tettstader, andre bynære. For å dokumentera meir spesifikke referansar til materialet brukar me «v $\rangle$ og $\langle\phi\rangle$ når me viser til landsdel og bokstavane A-F for einskildmenigheter. Aust og vest kan brukast som eit analytisk skilje der materialet viser forskjellar som kan knytast til sosiogeografiske tilhøve, men andre tilhøve kan visa seg å vera like viktige, slik som interne forhold i menigheten og kva personar som er i stab og råd. I så fall blir ikkje aust/vest aktuelle variablar. Alle menighetene hadde kateket/menighetspedagog og/eller trusopplæringsmedarbeidar, på heil- eller deltid, men sjølv om alle først nå hadde fătt pengar til utvikling av lokal plan, var dei komne ulikt i arbeidet med trusopplæringa. Menighetene i vest var komne eit år lengre i prosessen med sin lokale plan. Alle menighetene var i arbeidsprosessen med lokal plan begge gongene me intervjua dei.

Prosjektet har hatt ei tidsramme på tre år (2014-2016). Me har i to omgangar intervjua sokneprest, kateket/menighetspedagog og leiar for soknerådet, til saman 35 intervju med vel 20 forskjellige personar. ${ }^{3}$ Den første intervjurunden skjedde i november $2014 \mathrm{og}$ den andre runden omtrent eitt år seinare. Tanken var å sjå kva utvikling som hadde skjedd mellom intervjua. Det mest omfattande empiriske materialet kjem frå kvalitative forskingsintervju, på bakgrunn av ein intervjuguide med opne spørsmål.4 Kvart intervju varte i ca. ein time, og det blei gjort lydopptak. Me har ikkje laga ei ord-for-ord transkribering av intervjua, sidan fokuset vårt var på innhald og tema og ikkje på ein analyse av utsegner og ordbruk (Hammersley and Atkinson 2007:149-150), men me har laga oppsummeringar til intervjua me gjorde. ${ }^{5}$ Materialet inneheld òg intervju med mentor for fire av menighetene. I tillegg til intervjumaterialet har me hatt tilgang på anna dokumentasjon frå menighetene, som referat frå trusopplæringsutval, utkast til lokale trusopplæringsplanar og tilbakemelding frå bispedømmekonto-

3 I to av intervjua var undervisningsmedarbeidarane saman (gruppeintervju).

4 Døme på temafelt for intervjuguiden var informantane si umiddelbare forståing av trusopplæring, planprosessen, innhald og arbeidsformer i trusopplæringa, barn og unge sin plass i menigheten, forholdet til gudstenesta, rollane og samarbeidet til tilsette, frivillige og sokneråd, og spørsmål som gjekk på korleis dei ville nå alle døypte, om informasjonsarbeid, trusopplæring og folkekyrkje, og heilskapstenking i menigheten.

5 Likevel vel me å setja informantane sine utsegner i hermeteikn, sjølv om me ikkje kan garantera at dette var den nøyaktige ordlyden. Utsegnene fylgjer målforma elles i artikkelen. 
ret i vest på planutkast, men dette har mest fungert som utfyllande informasjon og dokumentasjon i høve til det som er kome fram i intervjua.

Den største utfordringa ved kvalitative forskingsintervju er at intervjuar er ein del av sjølve forskingssituasjonen. Intervjuforma kan best karakteriserast som eit samspel eller ein skapande dialog mellom forskar og den som blir intervjua, der begge er aktive i situasjonen. Me hadde ein viss kjennskap til menighetene og kjente fleire av personane me intervjua. At me kom som forskarar og ekspertar kan òg ha påverka intervjusituasjonen, og me opplevde til tider at dei me intervjua, sende spørsmåla tilbake til oss og bad om råd i forhold til konkrete situasjonar. I møte med denne såkalla «forskareffekten» har me vore bevisste på eigne verdiar og interesser, og samtidig erkjenner me at det er uråd å «samla» ikkje-tolka informasjon gjennom eit intervju. Det me særleg har hatt eit kritisk blikk på, er om informantane kan ha tatt ein del saker for gitt, og dermed ikkje sagt det, eller har svara for å tilfredsstilla det dei trudde me var ute etter. ${ }^{6}$

Trusopplæring skjer lokalt, og den lokale forankringa er ein verdi som er understreka i sentrale dokument (Kirkerådet 2010: kapittel 7-9). Me ser i analysen av materialet korleis den lokale konteksten påverkar både planarbeidet og tenkinga om trusopplæring i det heile. Då kan ein spørja om det finst nokon overføringsverdi av ei studie som denne? Målet med ei kvalitativ undersøking er ikkje å generalisera ut frå forskingsresultata, men å presentera einskildfunn så nøyaktig som mogleg. Heller enn generalisering er det fruktbart å snakka om identifikasjon og resonans, og at problemstillingar som blir reiste og innsikter som blir vunne, kan gå ut over det særeigne i konteksten og vekkja gjenlyd for andre i liknande situasjonar (Swinton and Mowat 2016:44-45).

I denne artikkelen har dei kvalitative forskingsintervjua vore mest nyttige for å forstå prosessane som skjedde i menighetene. Me har gjort eit nærstudium av referat frå einskildintervju, og materialet er blitt systematisk lese og kondensert gjennom ein kvalitativ meiningsanalyse. ${ }^{7}$ Me har anonymisert menighetene, og til tider har me brukt personlege pronomen bevisst villeiande for å gjera det vanskelegare å spora utsegner direkte tilbake til informantane.

\section{EKKLESIOLOGISKE DiMENSJONAR}

Det vil alltid skje ei utvikling i ein organisasjon eller ein menighet. Denne kan vera planmessig og styrt mot bestemte mål, eller den kan vera meir tilfeldig. Ingen organisasjonar er statiske over tid. Ein lokalmenighet er ein sosial stor-

6 Hammersley og Atkinson understreker at materiale frå intervju må sjåast på som sosiale fenomen, blitt til i og influert av spesifikke kontekstar. Likevel kan dei brukast som informasjonskjelder om hendingar og visa informantane sine perspektiv og praksisar (Hammersley and Atkinson 2007:120).

7 Arbeidsmåten svarer til det Steinar Kvale kallar «meaning condensation» (lesa gjennom materialet fleire gonger for å finna naturlege meiningssamanhengar og sentral bodskap) og «ad hoc meaning generation» (leita etter mønster og tema, kontrastar, samanlikningar, hyppighet av utsegner etc.). Kvale 1996:193-194, 203-204. 
leik i samfunnet, men den er samstundes særeigen i den forstand at trua på den treeine Gud, slik ho kjem til uttrykk i Bibelen og den kristne tradisjonen, er sentral i sjølvforståinga. Det har betydning for kva utvikling som er ønskeleg i ein kristen menighet, ikkje på detaljplanet, men på eit overordna nivå.

Det finst mange definisjonar på praktisk teologi, og ein av dei er gitt av dei engelske forskarane John Swinton og Harrieth Mowat: «Practical Theology is critical, theological reflection on the practices of the Church as they interact with the practices of the world, with a view to ensuring and enabling faithful participation in God's redemptive practices in, to and for the world.» (Swinton and Mowat 2016:7). Ein slik definisjon forstår lokalmenigheten i lys av Guds handling i og med verda, ifølge Harald Hegstad. Han kritiserer samstundes Swinton og Mowat sin definisjon for ikkje å ta tilstrekkeleg høgd òg for Guds skapande gjerning i verda, ikkje berre Guds frelsande gjerning (Hegstad 2012:12). I eit teologisk perspektiv må altså utvikling i menigheter vurderast i lys av korleis menigheten sin identitet og praksisar kan seiast å vera deltakande i det Gud gjer i verda, både på skapingsplanet og frelseplanet.

For å unders $ø$ ka korleis trusopplæringa kan vera ein faktor i å utvikla menighetene i Den norske kyrkja på ein kritisk og konstruktiv måte, kan det vera nyttig å presentera eit teologisk fundert perspektiv for kva identitet og praksisar som bør vera til stades i ein kristen menighet. Den teologiske og ekklesiologiske tenkinga i prosjektet «Menighetsutvikling i folkekirken» har vore styrande for korleis me har forstått menighetsutvikling i vår forsking på trusopplæring, og har fungert som ein basisteori for forskingsprosjektet. Derfor har me valt å presentera dei fem såkalla ekklesiologiske dimensjonane ved det å vera menighet som eit analyseperspektiv. Dimensjonane er normative i den forstand at dei seier noko om kva alle menigheter bør vera opptatt av, men leiarane i den einskilde menighet må på det grunnlaget gjera sine eigne val. Derfor blir dimensjonane her hovudsakeleg presenterte i spørsmålsform: 1) Ved tru: Kva betyr trua på den treeinige Gud for livet i menigheten? Ser folk i menigheten seg sjølv og sitt kvardagsliv i lys av evangeliet og den bibelske forteljinga? Er dei lydhøyre for kva Gud kallar dei til å vera og å gjera? Kva rolle spelar bibellesing og bøn? 2) I verda: Korleis kjem det til uttrykk i menigheten sitt liv at han er sendt til dei rundt seg, i lokalsamfunnet og til verda utanfor soknegrensene? I kva grad er menigheten medviten om ansvaret sitt for å visa omsorg for menneske og ansvar som forvaltarar av Gud sitt skaparverk? Kva forskjell gjer menigheten i lokalsamfunnet? 3) I fellesskap: Kva pregar menigheten som fellesskap, til forskjell frå andre menneskelege fellesskap? Er menigheten ein arena og verestad for alle døypte medlemmer, òg dei som søkjer kyrkja sine ulike tenester og riter? I kva grad blir menneske bekrefta på å høyra til fellesskapet og i kva grad blir dei utfordra til å koma nærare trua sine kjelder? Blir den einskilde verdsett og respektert med 
sin unike livserfaring og livssituasjon? 4) Med deltaking: $\AA$ høyra til menigheten er ikkje avhengig av graden av aktivitet. Får den einskilde moglegheit til å delta ut frå sine livserfaringar og føresetnader? Blir ulike former for deltaking verdsett? 5) I rørsle: Er menigheten medviten om si historie og eigenart, kva som er styrker og mindre sterke sider? I kva grad viser menigheten evne til å ta omsyn til endringar i lokalsamfunnet? Forstår folk i menigheten den konteksten dei er ein del av? Er menigheten ein endringsagent $i$ verda og er han sjølv i endring, ved å vera open for Guds leiing og lytta til bibelordet og gode råd frå medlemmer og medarbeidarar, og viser dei vilje til å ta risiko og å endra det som kan og bør endrast? Samla sett seier dimensjonane noko om heilskap. Dimensjonane er å forstå som ulike sider ved det å vera menighet, men det er berre ved å sjå dei som ein heilskap at ein får eit bilde av kva ein menighet bør vera og gjera. Heilskapstenking blir derfor eit viktig fokus når ein snakkar om menighetsutvikling. (Hegstad 2012:19; Hegstad 2011)

Dette er ein måte å skildra kva som bør vera viktig i ein kristen menighet, og det er fullt mogleg å kritisera dette perspektivet både for ikkje å vera omfattande eller breitt nok og samtidig å fokusera på element som andre vil meina ikkje er så viktige. Me meiner at dei ekklesiologiske dimensjonane er godt eigna til å reflektera over retning i menighetsarbeidet og sjå dei store linjene. Utfordringa er at dei kan koma til kort når det kjem til detaljplanet med kvardagens mange små og større saker, og det er ikkje gitt at dimensjonane omfattar alle sider ved materialet. Fokuset vårt i artikkelen ligg særleg på det meir overordna planet, og derfor meiner me at desse dimensjonane samla gir eit viktig teoriperspektiv. Andre teoretiske «briller» vil kunna vektleggja andre sider.

I gjennomgangen av det empiriske materialet vil me til denne artikkelen leita etter utsegner som, slik me tolkar dei, relaterer til dei forskjellige dimensjonane og uttrykkjer ei tenking om heilskap. Intervjuguiden var strukturert for å dekka heile forskingsprosjektet, medan desse fem dimensjonane og heilskap er våre tolkingsperspektiv for å unders $\emptyset$ kja korleis trusopplæringa kan ha eit potensial i å utvikla menighetene i Den norske kyrkja.

\section{Analyse aV det empiriske materialet}

I det fylgjande er materialet tematisk samanstilt, ut frå viktige funn som kan gi hjelp til å svara på problemstillinga for artikkelen. Me strukturerer empirien etter dei fem ekklesiologiske dimensjonane, og med eit sjette punkt om korleis heilskapstenking kjem til syne.

\section{Ved tru}

På spørsmålet om kva innhald informantane ser som spesielt viktig i trusopplæringa, er det fleire som er opptekne av den åndelege dimensjonen. Eit par av 
prestane nemner at trusopplæringa må hjelpa barna og familiane deira til ein enkel truspraksis, at trua må sitja meir i beina og kroppen; gi hjelp til ein måte å leva på. «Men me har av og til gått på aktivitetskarusellen; det er lettare å gjera enn å vera.» $(\phi \mathrm{C})^{8}$ Soknerådsleiar og kateket $(\phi \mathrm{A})$ legg vekt på formidling av bibelforteljingar og det å byggja ein relasjon til kyrkja, slik at barn og unge veit kor dei høyrer heime. Fleire meiner det er viktig å hjelpa folk til å takla livet i lys av gudstrua, få ei tru som ber i kvardagen, at dei kan bli trygge i den kristne trua.

Eitt av spørsmåla me stilte informantane, var kva dei ønskte skulle ha skjedd i menigheten fem år fram i tid. Dei fleste svara gjekk på tiltak, at desse omfatta alle alderstrinn og at dei hadde god oppslutnad, men det var òg ein del fokus på det åndelege innhaldet i tiltaka. Ein kateket $\emptyset$ nskte at både dei og barna skulle vera prega av bøn og gudsrelasjon. «Dette må starta i staben,» sa kateketen, «viss me ikkje er bevisste på det, så kjem det ikkje i tiltaka heller.» Kateketen sa vidare at «dette er ikkje eit problem overfor breidda. Når folk søkjer kyrkja, er det fordi me er noko anna enn andre institusjonar. Då må me stå opp for verdiane våre.» ( $\varnothing \mathrm{C})$ Utsegna kan tyda på at bøn og gudsrelasjon ikkje er framtredande i stabssamanheng; i alle fall ser det ut som kateketen meiner det. Ein annan av trusopplæringsmedarbeidarane $\emptyset$ nskte at trusopplæringa skulle vera med å utvikla barn og unge sine liv med Gud; hjelpa dei til å få personleg tru og liv (vF). Ein prest funderer på korleis dei kan fă til å invitera foreldre til samlingar om trua. Foreldra køyrer ofte barn på tiltak, og så sit dei og ventar og høyrer på. Han ønskjer å utfordra foreldra, men veit ikkje heilt korleis (vE). Han er òg bevisst på at målet med involvering av dei «ikkje så aktive» i menigheten må vera å hjelpa dei over i trusfellesskapet, ${ }^{9}$ noko òg soknerådsleiar i $\phi \mathrm{C}$ meiner er viktig. Ein annan av prestane har lagt merke til auka deltaking i nattverden: «Fleire blir med på nattverd når det er dåp eller trusopplæringstiltak, spesielt når det er ein vandring i kyrkja, då folk ikkje ser så nøye kva dei er med på» $(\phi C)$.

Trusopplæringa si tilknyting til gudstenesta og kyrkjerommet har vore eit særmerke heilt frå fors $\emptyset$ ksfasen av reforma (Hegstad, Aagedal, og Selbekk 2008:126). I dei unders $\varnothing$ kte menighetene har barn og unge og trusopplæringstiltak ein naturleg og integrert plass i gudstenesta, og det er gjennomgåande stor semje om dette. Hegstad peikar på gudstenesta som «hjerteslaget» i menigheten sitt liv (Hegstad 2011:13). Ein av prestane er ganske sterk i si understreking: «Trusopplæringa må henga saman med gudstenestelivet, elles heng ho i lufta.

8 Utsegna kan tolkast i lys av at trusopplæringa først og fremst fokuserer på å “gjera”. Det er lagt opp til tiltak og aktivitetar, og det finst utsegner i materialet om at trusopplæringsmedarbeidarane mest er opptatt av å gjennomføra praktiske tiltak.

9 I eit forsøk på å gi ein peikepinn på grad av oppslutnad og deltaking mellom medlemmene i Den norske kyrkja har det vore vanleg å snakka om «trusfellesskap» og «folkekyrkje». Ein stor del av medlemmene i kyrkja sluttar opp om kyrkjelege handlingar som dåp, konfirmasjon og gravferd (folkekyrkjedelen), medan færre deltar regelmessig i gudstenester (trusfellesskapet) (Hegstad 2012:20). 
Det trengst både for trusopplæringa og for gudstenesta 》 (vD). Han ser på trusopplæringa som den viktigaste gudstenestereforma i menigheten og har eit $\emptyset$ nske om at trusopplæringa skal reformera gudstenesta. Ein annan av prestane uttrykkjer bekymring for ein mogleg infantilisering av kyrkja. I samband med trusopplæringstiltak blir gjerne dei enkle tinga («Gud er glad i deg») forkynt, og vaksne har behov for meir (vF). Kanskje utsegna hans like gjerne er ei utfordring til forkynnarane? Barn og unge treng òg sann og ærleg forkynning om viktige livstema, slik at den kristne trua kan bidra til livsmeistring. Ein annan prest seier at det først vil bli kontroversielt dersom trusopplæringa overtar gudstenestene, slik at alle blir spesialgudstenester $(\varnothing \mathrm{A})$. Fleire skulle $\emptyset$ nskt at det vanlege gudstenesteuttrykket òg hadde blitt endra, slik at det var ein naturleg plass for barn og unge på alle gudstenestene i menigheten (vD, vE).

Dei som har ansvar for trusopplæringa i vE, ser det som ein fare at tiltaka skal bli underhaldning, utan eit godt innhald. Dei er samde om at det ikkje skal vera slik, men det å fylgja opp tiltaka med godt innhald er ikkje alltid like lett i praksis. «Godt» innhald her synest å peika på åndeleg substans. Ein av soknerådsleiarane seier at dei etter kvart er blitt meir bevisste på innhaldet i tiltaka, ikkje berre at det skal skje noko $(\varnothing \mathrm{A})$.

Det er eit par døme i materialet på at det å fylgja systematikken i lokal plan for trusopplæring blir opplevd som hemmande. Ein av trusopplæringsmedarbeidarane fortel at han til tider opplever planen som eit fengsel fordi han ikkje sjølv får velja bibeltekstar og songar. Menighetspedagogen responderer på ein måte me vil karakterisera som «mild irettesetjing», og understreker at det må vera ein progresjon i opplæringa, slik at det ikkje blir unødig gjentaking i fleire tiltak $(\mathrm{vF})$. Dette viser at det må vera ei bevisst leiing for å bevara det systematiske og samanhangande innhaldet i planen.

I ein av menighetene registrerer me ei viss usemje om ein skal satsa på lågterskeltilbod eller tiltak med meir tyngde. Ein kan her snakka om utvikling som breidde (kvantitativt) eller utvikling som djupn (kvalitativt). Kateketen opplever likevel at ei slik spenning i trusopplæringsutvalet ikkje er noko trugsmål, men kan vera nyttig sidan det gir sjanse til å drøfta desse tinga vidare $(\emptyset \mathrm{B})$. Ein annan kateket er frustrert over forholdet mellom det statistisk målbare og den meir usynlege utviklinga, og seier: «Forståing av menighet er avgjerande, kva menighet vil me utvikla?» Spørsmålet er om fokuset skal vera på trusfellesskapet eller folkekyrkjedelen, og kateketen $\emptyset$ nskjer meir drøfting av desse tinga i staben $(\varnothing \mathrm{C})$.

Det teologiske innhaldet i trusopplæringa blir vektlagt av informantane, og det synest å vera ei ståande utfordring å gi tiltaka eit innhald som har trua på Gud som fokus. Materialet viser variasjon i synspunkt. Nokre $\emptyset$ nskjer meir vekt på ein personleg gudsrelasjon, medan andre har ei breiare tilnærming. Ulik til- 
nærming til dette blir helsa velkommen av nokre informantar, men det blir òg etterlyst grundigare drøfting av innhaldet i trusopplæringa, som heng saman med kva delar av menigheten ein ønskjer å utvikla.

\section{I verda}

«At kirken er sendt til verden, gir et viktig perspektiv på alt vi holder på med,» seier Hegstad. «Vi kan simpelthen ikke bare være opptatt av oss selv og vårt eget menighetsliv, vi må ha vår oppmerksomhet rettet utover, mot den verden vi er sendt til» (Hegstad 2011: 14). Når me ser etter dette perspektivet i materialet, finn me mest utsegner om å vera utåtvende ved betre kommunikasjon og informasjon i eige lokalsamfunn. Ein av kateketane meiner menigheten har låg kunnskap om kommunikasjon, og seier: «Me treng ein eigen informasjonsstrategi!» $(\varnothing \mathrm{C}) .^{10} \mathrm{I}$ invitasjon til tiltak brukar menighetene mange forskjellige kanalar: Personleg kontakt, brev, facebook og andre sosiale medier, kyrkjelydsblad, heimesider og sms (vF). Den beste informasjonen - og reklamen for tiltak - er når barna trivest og snakkar til andre barn om dette (vE), og at det står gode medarbeidarar bak tiltaka, som folk har tillit til (vD). Ein soknerådsleiar peikar på viktigheten av kyrkjelydsbladet, som òg er ein slags bygdeblad med informasjon om andre aktiviteter i nærmiljøet. «Men språket der kan nok vera litt uforståeleg for nokre, » medgir han (vF). Bevisstheten om ikkje å bruka internt språk når ein $\emptyset$ nskjer å informera breitt, ser fleire som eit viktig tema ( $\emptyset \mathrm{A})$. I ein av vest-menighetene er presten opptatt av kva språk ein bruker i omtale av barn. «Me må snakka om at døypte barn og unge høyrer til Jesus og ikkje er objekt for omvending, » seier han (vD). Han trur denne «omvendingsretorikken» går på språk meir enn tenking, men kva språk ein bruker, er ikkje utan betydning. Alt som blir gjort for å byggja gode relasjonar i lokalmiljøet, byggjer omdømmet til kyrkja. «Når ein høyrer kva kyrkja gjer, vil det vera fleire som tenkjer at 'her $\emptyset$ nskjer eg at barnet mitt skal vera med', » seier ein av prestane ( $\emptyset \mathrm{B})$.

Me tolkar informantane sine utsegner ovanfor til hovudsakeleg å dreia seg om kommunikasjon med kyrkja sine eigne medlemmar. Informantane er representantar frå stab og sokneråd, og dei jobbar for at flest mogleg av dei døypte barna skal delta i trusopplæringa. Når det gjeld utsegna om gode relasjonar i nærmiljøet, synest dette å gjelda lokalsamfunnet meir generelt. Materialet viser at dimensjonen «i verda» berre er svakt til stades i materialet vårt. Her er mange spørsmål som ikkje får svar: Kva tenkjer informantane om å nå ut med informasjon om menigheten og trusopplæringa til andre enn kyrkja sine medlemmer? Korleis kjem det fram at menigheten er sendt for å gjera ein forskjell i nærmiljøet? Kva med eit sterkare fokus på å forkynna evangeliet i ord og gjerning for

10 Ei undersøking viser at når dei undervisningstilsette blir spurte om kva behov dei har for vidareutdanning, rangerer dei PR og informasjon høgast (Horsfjord et al. 2015:78). 
dei udøypte i lokalsamfunnet? Korleis blir trusopplæringa utfordra av - og sjølv utfordrar - det fleirkulturelle og fleirreligiøse samfunnet? Kva med impulsar frå den verdsvide kyrkja, og kva med misjon og diakoni i nærmiljøet og globalt? ${ }^{11}$

\section{I fellesskap}

Med fellesskap tenkjer me her både på alle døypte medlemmer og på dei som faktisk er til stades i ulike trusopplæringstiltak. Informantane er samstemte i at trusopplæringa gjeld alle døypte. Dersom dei intervjua skulle samanlikna trusopplæringa med ein bil, valde mange ein stor bil eller ein buss med god plass til mange. Den første tanken dei fekk når me sa ordet «trusopplæring», gjekk òg mykje i retning av noko for alle døypte, breiddetiltak. «Me kan ikkje døypa 100 og berre ha ambisjon om å prega tru for $30 \mathrm{av}$ desse, » seier ein av prestane (vD). Me tolkar dette slik at trusopplæringsplanen sitt fokus på alle døypte (Kirkerådet 2010:4) har festa seg hos informantane. Ein kateket uttalar seg slik: «Det er blitt eit større «me» - det er ikkje berre dei som er fødde inn i og har vakse opp i kyrkja som høyrer til» $(\varnothing \mathrm{A})$. Samstundes vedgår kateketen at dei burde nok ha fokus på og samtala meir om at trusopplæringa er for alle. Ein annan kateket understreker at ein skal relatera til alle døypte og nå så mange som mogleg, men antyder vidare at dei skulle vera godt nøgde om dei jamt over kunne få meir enn $20 \%$ oppslutnad i tiltaka. Det verkar som plassen i kyrkja ikkje tillét meir enn at $25-30 \%$ av dei døypte kjem $(\varnothing \mathrm{C})$. Materialet viser til andre tiltak med mykje høgare oppslutnad, men òg til samtalar om kor få det kan vera i eit tiltak før avlysing, og det blir gjennomgåande opplevd som ei utfordring å få barn og unge til å delta, særleg på lite innarbeida tiltak. Årsaker kan vera konkurranse med andre om barn og unge si tid, men òg at trusopplæringa ikkje blir opplevd viktig nok for mange, sjølv om dei ikkje er imot kyrkja $(\emptyset \mathrm{A})$. Me ser her ein bevisstheit om at idealet er alle døypte, men me kan stilla spørsmål ved om dei har tatt dette på alvor i praksis. Det er òg verd å merka at informantane i stor grad har fokus på at fellesskapet skal vera ope for alle, men det er mindre tale om korleis dette fellesskapet skal vera, eller kvalitetane ved fellesskapet.

Trusopplæringstiltak som ein del av gudstenesta har opna opp kyrkja for fleire menneske, og fordi det er fleire gudstenester som er ein del av tidsavgrensa tiltak, er det fleire «kyrkje-uvante» nå enn før $(\phi \mathrm{C})$. Fleire antyder at trusopplæringa har endra gudstenestedeltakinga. Nå er det færre av dei faste gudstenestegjengarane kvar sundag og fleire av dei som fylgjer med barna sine på ulike gudstenester $(\emptyset \mathrm{A}, \mathrm{vF})$. Dette kan ha samanheng med at det er nokre av dei faste som held seg borte frå ein del av gudstenestene, kanskje fordi det er blitt meir uro på gudstenester med sterkt innslag av mindre barn. Ein kateket

\footnotetext{
11 Menighetene sine lokale planar for trusopplæring har alle eit punkt om misjon og diakoni, sidan desse dimensjonane i ei heilskapleg trusopplæring må kommenterast i planen (Kirkerådet 2010:45). Likevel er det verd å merka seg at så lite av konkrete utsegner i intervjua relaterer seg til denne dimensjonen.
} 
antyder dette då ho seier: «Eg veit at andre synest det har vore litt for mykje involvering med barn, men eg har ikkje orka å ta den kampen.» (øA) Kanskje årsakene til eit endra gudstenestem $ø$ nster like gjerne er at gudstenestedeltakinga generelt er i endring? ${ }^{12}$

Trusopplæringa fører til at heimane blir involverte i større grad enn før. I fleire menigheter finn me ei bevisst familietenking. Det viser seg at trusopplæringa involverer foreldre som ein ikkje nådde på same måte før. I karneval for sjuåringane blei heile familien involverte $(\phi \mathrm{C})$. «Ein ny generasjon er i ferd med å koma inn på huset, » seier ein av soknerådsleiarane (vF). Dette kan skje ved at foreldre fylgjer barna sine eller ved at foreldre blir inviterte med i oppgåver i fellesskapet.

Informantane understreker sterkt at alle døypte høyrer til i fellesskapet i menigheten. Likevel verkar det som fleire er nøgde med at berre $25 \%$ av dei døypte er med i trusopplæringstiltak, og gjennomgåande er det ei utfordring å få barn og unge til å delta. Gudstenestefellesskapet er blitt utvida gjennom trusopplæringa, men samstundes er det nokre som ikkje kjem så regelmessig, kanskje fordi det er blitt meir uro når barna blir involverte. Informantane tenkjer ikkje at trusopplæringa berre gjeld barna. Gjennom barna si deltaking blir òg fellesskapet utvida til å omfatta barna sine familiar.

\section{Med deltaking}

Det er mogleg å vera deltakar på mange måtar i ein menighet. Nokre er nokså passive, medan andre kan kallast aktivitetskristne (Høeg and Gresaker 2015:22). Hegstad understreker at «tilhørigheten til menighetsfellesskapet ikke avhenger av graden av aktivitet» (Hegstad 2011:21). «Eg synest det er fint å spørja foreldre som ikkje nødvendigvis er aktive i menigheten frå før og har positive erfaringar med dette. [...] Det å spørja dei, kan òg vera ein bekreftelse for dei,» seier ein av trusopplæringsmedarbeidarane (vE). Andre er bevisste på å trekkja foreldra inn i konfirmantundervisninga $(\emptyset \mathrm{A})$. $\ll$ Me har gode $\mathrm{d} \emptyset \mathrm{me}$ på at meir perifere medlemmer blir inviterte med i oppgåver, > seier ein soknerådsleiar (vE), og han held fram: «Dei begynner heilt bak, og så beveger dei seg framover. Eg trur alle har ei spire av tru, og det er ikkje vår sak å bedømma om den held. Det finst ein søken, men òg ein redsel.» Det blir likevel opplevd som ei utfordring å få foreldre til å stilla på tiltak, og i samband med ønsket og behovet for frivillig innsats, vurderer ein av kateketane å setja det opp som eit krav for foreldre som melder på eit barn, å delta i ei praktisk oppgåve $(\phi \mathrm{C})$. Andre meiner dette vil ha negative konsekvensar, sidan kyrkja må basera deltaking på barn og foreldre sin

12 Dette spørsmålet stiller me oss på bakgrunn av et generelt kjennskap til gudstenestelivet i Den norske kyrkja. Almenne samfunnstrekk som større mobilitet, at fleire reiser på eigne hytter i helgene og lågare grad av forplikting kan like gjerne vera ein årsak til at nokre av dei som tidlegare deltok jamnleg i gudstenesta nå deltar sjeldnare. 
frie vilje. Ein viktig strategi overfor foreldra er det nokre kallar å «løfta opp» foreldregruppa, særleg for dei minste barna. Grunnen er ei overtyding om at den viktigaste trusopplæringa skjer $i$ heimen. Ein av prestane utfordrar $i$ dåpssamtalen foreldra på at det er dei som legg premissa for trusopplæringa $(\emptyset \mathrm{B})$. Mange foreldre er for usikre til å gjera noko trusopplæring heime, tenkjer ein av kateketane, og derfor må dei hjelpast til å gjera dei små, avgjerande tinga, slik som bordvers og kveldssong $(\varnothing \mathrm{B})$. Ein av trusopplæringsmedarbeidarane er bevisst på at ho sender med barna heim bibelvers og songar frå tiltak $(\mathrm{vF})$.

Det blir opplevd utfordrande å få til ein integrasjon mellom, på den eine sida, trusopplæringa med tidsavgrensa tiltak og, på den andre sida, det kontinuerlege barne- og ungdomsarbeidet. Ein av sokneprestane kallar dette «den store pr $\varnothing$ vesteinen». Han understreker at leiarane i kor, speidar, sundagsskole etc. bør få oppleva at trusopplæringa er ein ressurs òg for dei, og ikkje konkurrerande. Ein må jobba for eit samverke, og han meiner det skal lite til før dette går gale ( $\varnothing \mathrm{A})$. Me har antydningar i materialet på at leiarar i det kontinuerlege arbeidet meiner det er urettferdig at dei friske pengane berre skal gå til tidsavgrensa tiltak ( $\varnothing \mathrm{A})$. Samtidig er særleg ein av prestane opptatt av at trusopplæringsmedarbeidarane driv med det dei skal og ikkje blir oppslukte av kontinuerleg arbeid (vD). Fordi dei som driv det kontinuerlege arbeidet, har rykte på seg på å vera gode på barne- og ungdomsarbeid, vil nokre helst halda på det gamle. Informantane ser samtidig at trusopplæringa omfattar mange som ikkje kjem på kontinuerlege tiltak. Ein av prestane seier: «Dette er den einaste kontakten mange barn og unge får med menigheten. Mange av barna som kjem på breiddetiltak, ser me aldri meir.» (vE) Det blir opplevd som ei utfordring å få barn og unge med vidare frå tidsavgrensa til kontinuerlege tiltak. Ein prest har ein interessant refleksjon når det gjeld effekten av trusopplæringa over tid. Han bruker konfirmantane som døme og seier at når dei unge kjem til konfirmasjonsførebuinga, er dei kjende fordi dei har vore med i tiltak tidlegare. Dei kjem ikkje til noko som er heilt nytt for dei. I menigheten er dei tydelege på å invitera til kontinuerlege tilbod når eit tidsavgrensa tiltak er over. På den måten knyter dei tiltaka til kvarandre (vF).

Dei som er tilsette i menigheten, har nøkkelrollar i verksemda. «Omfanget av trusopplæringa og heilskapssynet på læring utfordrar staben til tverrfagleg samarbeid, [...]»), står det i den nasjonale planen (Kirkerådet 2010:34). Samarbeidet gjeld både planarbeidet og planlegging og gjennomføring av tiltak, det gjeld internt i staben, men òg mellom stab, frivillige medarbeidarar/heimen og sokneråd. Materialet vårt viser at samarbeid er på agendaen i menighetene, og fleire uttrykkjer glede over godt samarbeid både internt i staben og mellom sokneråd, stab og frivillige. Likevel skaper det frustrasjon og utfordringar i samarbeidet at nokre i staben lett melder seg ut og tilsynelatande manglar entusiasme for trusopplæringa. Trusopplæringsmedarbeidar ber ofte eit tungt ansvar 
for planarbeidet, og det er ikkje alltid dei andre er reelt involverte. «Alle støttar trusopplæringa, men spørsmålet er å engasjera seg i det, » seier ein trusopplæringsmedarbeidar (vE). Soknerådsformannen i same menigheten meiner jamvel at soknerådet må påleggjast å vera med på trusopplæringa, som han meiner er lokomotivet i menigheten. Det han seier, peikar ikkje først og fremst på soknerådet sitt lovpålagte ansvar for å godkjenna lokal plan; det går heller på eit ønske om at dei er reelt engasjerte i trusopplæringa. ${ }^{13}$

Trusopplæringa har mange tidsavgrensa tiltak, og fleire informantar er opptekne av å leggja til rette for deltaking frå ein større del av medlemmene enn dei som er mest aktive frå før. Det å bli spurt om konkrete oppgåver, kan vera ei stadfesting av å høyra til og bli rekna med. Informantane peikar på at foreldra si rolle i trusopplæringa er avgjerande, og derfor sender dei med materiell til heimane eller gir hjelp til trusopplæring i familien på annan måte. Gjennomgåande blir det likevel opplevd som ei utfordring å få foreldre til å vera med på trusopplæringstiltak.

Samarbeid tilsette imellom og mellom tilsette og frivillige opplever informantane som viktig, men vedgår at det kan skapa frustrasjon. Det er i nokre menigheter tilløp til rivalisering mellom trusopplæringa og det kontinuerlege barne- og ungdomsarbeidet. Nokre i staben (trusopplæringsmedarbeidarar) kjenner på at dei ber på for mykje ansvar for trusopplæringa.

\section{I rørsle}

«Et nødvendig utgangspunkt for god menighetsutvikling er å søke å forstå den kontekst man er en del av på en så allsidig måte som mulig,» hevdar Hegstad (Hegstad 2011:26). I nasjonal plan heiter det at «Trusopplæringa i kyrkjelyden må utviklast ut frå lokale behov og føresetnader» (Kirkerådet 2010:4). Medarbeidarane i menighetene er bevisste på denne utfordringa. I eitt av planutkasta les me at det er avgjerande at folk i menigheten kjenner lokalmiljøet sitt og si tid for å kunna leggja til rette for ei fornya og relevant trusopplæring. Det inneber å henta inn statistikk og annan relevant informasjon $(\phi \mathrm{C})$. Lokalmiljøa inneber forskjellige utfordringar for menighetene, til dømes fordi det religiøse landskapet er så ulikt. Ei anna utfordring for den lokale forankringa av tiltaka er at trusopplæringsmedarbeidarane i fleire av menighetene ikkje sjølve bur i menigheten $(\emptyset \mathrm{A}, \mathrm{vD}, \mathrm{vF})$. Dermed kjenner dei ikkje dei potensielle frivillige medarbeidarane og dei er berre nokre gonger involverte i gudstenestene.

For at tiltaka skal få brei oppslutnad må dei vera forankra i det som rører seg hos folk flest, meiner ein av kateketane $(\varnothing \mathrm{C})$, og det blir etterlyst vilje til å utvikla seg i takt med ungdommane si utvikling (vE). Dersom tiltaka blir lagt til rette slik at dei svarer til eit behov hos familiane, vil dei få oppslutnad i konkurranse

13 Dette er eit omfattande temafelt, og me viser til meir utførlege drøftingar i Birkedal, 2017 og Austnaberg 2017. 
med andre positive aktivitetar, trur ein av prestane $(\emptyset \mathrm{A})$.

Materialet inneheld ein del om lokal forankring av trusopplæringa og det å spela på lag med konteksten, men gjennomgåande er det ikkje mykje fokus på det å vera i rørsle. Kanskje har dette samanheng med lite merksemd på perspektivet «i verda» og kan tyda på at menighetene har meir enn nok med sine eigne aktivitetar?

\section{Heilskap}

I den nasjonale trusopplæringsplanen Gud gir - vi deler er det mykje snakk om ei heilskapleg trusopplæring (Kirkerådet 2010:18, 27, 41). I materialet vårt finn me tale om heilskap i forskjellige betydningar: Heilskap i forhold til det einskilde barn, i planarbeidet, i samarbeidet mellom stab, råd og frivillige, i forhold til det kontinuerlege barne- og ungdomsarbeidet i menigheten og i forhold til annan kristen aktivitet i soknet. Det viser seg likevel at det til dels har vore ei utfordring å få trusopplæringa til å bli ein del av heilskapstenkinga i menigheten og ikkje bli verande som eit prosjekt på sida av verksemda elles. «Trusopplæringa må ikkje bli «ein organisasjon i organisasjonen», det vil vera å mislukkast totalt,» seier ein soknerådsleiar $(\emptyset \mathrm{A})$. Ein annan soknerådsleiar reflekterer over kor vanskeleg det er for eit sokneråd å få oversikt over heilskapen; det krev eit enormt arbeid for ein frivillig. Han ser det som ei utfordring at det ikkje er nokon som har heilskapsoversikt sidan det i ein menighet er ulike arbeidslag (vE). Ein av prestane gir uttrykk for usikkerheit om kva trusopplæringa kan fă av betydning når han seier: «så det står igjen å sjå kva trusopplæringa bidrar med til heilskapen.» ( $\emptyset \mathrm{A})$ Me anar ei litt avventande, spørjande haldning til moglegheita for å tenkja heilskapleg.

Ikkje minst arbeidet med lokal plan utfordrar til heilskapstenking. Sjølve utforminga av planen har medført behov for felles møtepunkt, og forskjellige innsteg hos aktørane medfører gjerne at ein samla sett får eit større og meir variert blikk på trusopplæringa. Det er eit pålegg i nasjonal plan at den lokale planen skal innehalda strategiar for korleis ulike delar av menigheten skal inkluderast i tenkinga om ei heilskapleg trusopplæring. Det er omtalt som 11 dimensjonar, og dei er lista opp som verktøy for utvikling av den lokale planen (Kirkerådet 2010:27, 45). Utkasta til lokale planar frå alle menighetene har då sjølvsagt desse dimensjonane med, men det er store variasjonar i kor fyldig dei er utforma og i kva grad det er samanheng mellom dimensjonane og dei konkrete tiltaka. Vest-menighetene, som alle har fătt kommentarar frå bispedømmekontoret på sine utkast til planar, har òg gjennomgåande fătt kommentarar til denne delen av planen. Materialet synest å antyda at arbeidet med dimensjonane i nokre av menighetene har blitt oppfatta som eit slags «pliktløp», som måtte vera ein del av planen. Det er usikkert kor stor rolle denne delen i praksis 
har spela for heilskapstenkinga. «Det er ikkje lett å forstå kva dette handlar om, » seier ein av prestane (vD). «Det blir metaspråk om strategisk tenking. For praktikarane blir dette «vås»). Det er krevjande å tenkja slik, og eg trur det har begrensa verdi.» Viss arbeidet med dimensjonane berre blir gjort for planen sin del, vil effekten av refleksjonane vera liten, slik ein av soknerådsleiarane uttrykkjer det: «Det nyttar ikkje med ein god perm med mange gode prosedyrar, viss ein ikkje har dei rette folka.» (vE)

Ei utfordring fleire av informantane nemner, er at det verkar som mange ikkje heilt forstår kva trusopplæring er. Det gjeld både soknerådet, foreldre, dei meir faste i menigheten og elles i soknet ( $\phi \mathrm{C}, \mathrm{vD})$. Ein av menighetspedagogane seier at ho skal ha mange eksemplar av den nasjonale planen med seg til møtet med soknerådet, og ho skal spørja dei konkret kor mange som har lese planen $(\mathrm{vF})$. Foreldra har vanskar med å skilja trusopplæringa frå det barna får i skolen, og med konkurranse om fritidsaktivitetar er tydeleg kommunikasjon om trusopplæringa nødvendig for at dei skal prioritera dette ( $\varnothing \mathrm{C}$ mentor). Manglande kjennskap til trusopplæringa er eit hinder for eigarskap til denne. Ein måte å skapa eigarskap på, er gjennom frivillig medverknad $(\emptyset \mathrm{C})$. Ein føresetnad for å lukkast er å ha eit eigarforhold til planen, seier ein av soknerådsleiarane ( $\emptyset \mathrm{A})$, og det kan ein få ved å vera involvert $\mathrm{i}$ utviklinga av planen.

Det er interessant å leggja merke til korleis fleire av informantane framhevar trusopplæringa som menighetsutvikling. ${ }^{14}$ Ein av menighetene kalla inn til eit stormøte om trusopplæringa i ein tidleg fase etter tildeling av pengar, der stab, sokneråd og leiarar i alle delar av menigheten var inviterte. I innkallinga hadde dei skrive at bevisst og god trusopplæring vil gi menighetsutvikling, og dei bad om hjelp til å finna ut korleis dei kunne utvikla trusopplæringa og korleis dei kunne bli ennå betre til det $(\mathrm{vF})$. Ein soknerådsleiar seier det slik: «Trusopplæring er noko av det viktigaste ein har gjort i Den norske kyrkja dei siste 30 åra.» (vD) Presten i same menigheten seier at han er overtydd om at trusopplæringskulturen vil vera deira menighetsutvikling. Han utdjupar ikkje kva han meiner med «kulturen», men det er nærliggjande å tenkja på det som er hovudfokus i trusopplæringa: Arbeid med barn og unge, der alle døypte systematisk blir inviterte til tidsavgrensa tiltak. Ein annan av prestane seier at trusopplæringa skal integrerast $\mathrm{i}$ heile menigheten og at den slik vil vera med å prega alt menighetsarbeid $(\phi \mathrm{B})$. Ein tredje seier at han bruker mykje tid og ressursar på trusopplæringa, og held fram: «Dette er noko av det viktigaste eg

14 Det kan ikkje utelukkast at utvalet av menigheter kan ha hatt betydning for svara informantane gir. Alle menighetene var eller hadde vore deltakarar i menighetsutviklingsprosjekt, og vårt kjennskap til fleire av dei me intervjua kan òg ha påverka resultata. Dei visste at me var opptekne av menighetsutvikling og kan ha gitt oss svar ut frå det dei tenkte me ønskte. Me har såleis her eit døme på ein mogleg «forskareffekt». Opplevinga vår er likevel at desse utsegnene først og fremst synest å ha sin bakgrunn i ei oppdaging av kor avgjerande trusopplæringa er for kyrkja. Berre nye studiar av trusopplæringa sitt potensial for menighetsutvikling kan gi eit fyldigare svar på mogleg påverknad. 
er med på. Denne menigheten er opptatt av menighetsutvikling, og dette er jo menighetsutvikling.» (vE). Han seier vidare at han ikkje er sikker på at folk forstår at trusopplæringa handlar om framtida for folkekyrkja. Fleire andre poengterer noko av det same, og me synest å spora ein viss desperasjon i utsegnene deira: «Trusopplæringa er einaste sjanse for å halda kunnskapsnivået om kristendommen oppe.» $(\phi \mathrm{B})$ 《Viss me ikkje lukkast med trusopplæringa, låser me kyrkja. Me må lukkast!» (vF) «Eg har berre blitt sikrare på at trusopplæringa var nødvendig.» (vD)

Materialet vårt viser òg at idealet og verkelegheita ikkje alltid stemmer overeins. «Ideelt sett burde trusopplæringa vera eit drivhjul, men me er ikkje heilt der,» seier trusopplæringsmedarbeidarene i vE. Kanskje utsegna likevel tyder på at dei er på veg dit? Ein av kateketane konstaterer: «Det er nok mest slik at trusopplæringa er for barn og unge, ikkje at trusopplæring er noko som gjeld heile menigheten, slik at me alle deltar og blir ein lærande menighet.» ( $\emptyset \mathrm{A})$

Menighetene har fått hjelp til å tenkja heilskapleg gjennom arbeidet med lokal plan for trusopplæring. Likevel er det slik at trusopplæringa lett kan bli ein aktivitet for seg sjølv, som ikkje er integrert i verksemda elles i menigheten. Fleire informantar uttrykkjer ei sterk forventning om at trusopplæringa kan bidra positivt til utvikling av menigheten og ser denne satsinga som avgjerande for folkekyrkja si framtid. Når det gjeld praksis i menighetene, ser informantane at det ennå er eit stykke veg å gå før trusopplæringa kan ha ei slik rolle.

\section{Oppsummerande DRøFTING}

Eit hovudfunn i materialet er at informantane synest samstemte i forståinga av kven som høyrer til menigheten. At trusopplæringa femner alle døypte barn og ungdom mellom 0 og 18 år er ikkje noko nytt. Det har vore understreka $\mathrm{i}$ formålet for trusopplæringa heilt frå starten (Kirkerådet 2010:4). Denne understrekinga ser ut til å ha festa seg på ein slik måte at informantane inkluderer og reknar med alle medlemmene i kyrkja i menighetstenkinga. Dette er ikkje sjølvsagt ut frå tradisjonelle skiljelinjer mellom trusfellesskapet og folkekyrkjedelen av medlemmene (Hegstad 2012:20), eller aktivitetskristne, kulturkristne og distanserte medlemmer, som er ein annan måte å beskriva folkekyrkja på (Høeg and Gresaker 2015:21-23). Det er ikkje snakk om å bedømma grad av kristen tru eller praksis til dei som deltar. Alle blir bekrefta som fullverdige medlemmer.

Likevel finst det ein del utsegner i materialet vårt som problematiserer dette. Ei av desse er at fleire informantar har som mål å hjelpa barn/unge og familiane deira til å bli meir regelmessige deltakarar i trusfellesskapet, eller det ein informant kallar «omvendingsretorikk» i omtale av døypte barn. Informanten trur slik omtale går på språk, men ein kan stilla spørsmål ved kva som ligg bak ein slik språkbruk, og i alle fall er språket med og formar tenkinga. Kan det forståast 
slik at trusfellesskapet er ein reiskap for å nå den folkekyrkjelege breidde, noko som er ei legitim oppgåve? Viss ein ikkje har eit trusfellesskap, har ein heller inga kyrkje som samlast om ord og sakrament. Eller kan det tolkast slik at deltakarar i trusfellesskapet ser på medlemmene i folkekyrkjedelen av medlemmene som «misjonsmark», og med det underkjenner at døypte medlemmer er ein del av menigheten? (Hegstad 2012:21). Eller kan ein tolka ønsket om at fleire skal bli meir regelmessige deltakarar i trusfellesskapet som uttrykk for uro over at ein så stor del av kyrkja sine medlemmer ikkje tar del i det fellesskapet dei er døypte inn i? (Hegstad 2009:101)

Det er nokre informantar som undrar seg over at foreldre og ungdom ikkje opplever trusopplæringa viktig nok til å prioritera henne, noko som i gjennomsnitt fører til at det berre er 25-30 \% av dei døypte som i praksis deltar på tiltaka. Dette kan ha fleire årsaker: Nokre tenkjer at skolen gir tilstrekkeleg opplæring gjennom religionsundervisninga. Andre kjenner ikkje dei sentrale leiarane $\mathrm{i}$ tiltaka og er usikre på om dei kan stola på desse. Mange medlemmer i kyrkja manglar tydeleg informasjon om kva trusopplæring er, og ei moglegheit er sjølvsagt at dei ikkje er interesserte eller ser verdien av denne opplæringa. Høeg og Gresaker hevdar at gruppa dei kallar kulturkristne, som utgjer 60-70 prosent av medlemmene, ikkje er avvisande til å senda barna sine på organiserte kristne aktivitetar (Høeg and Gresaker 2015:22). Det skulle altså vera stort potensial for at fleire enn 25-30\% av dei døypte barna deltar på tiltaka i trusopplæringa. Samanfattande uttrykkjer informantane at det gjennom trusopplæringa blir eit større «me» som høyrer til i menigheten, og det er i seg sjølv menighetsutvikling: fellesskapet er blitt meir omfattande.

Eit viktig funn i materialet er at informantane sterkt understreker at trusopplæringa må hjelpa barn og unge til å bli trygge i den kristne trua og få ei tru som ber i kvardagen, slik at dei kan takla livet i lys av gudstrua. Dette svarer til intensjonane i den nasjonale planen, med aspekta «tru og tradisjon i kyrkja», «kristen tru i praksis» og «livstolking og livsmeistring» (Kirkerådet 2010:15). Likevel gir ein del informantar uttrykk for at det er vanskeleg å halda på dette fokuset. Det verkar lettare å laga ein «happening». Nokre meiner dei er blitt flinkare til å vera bevisste på det kristne innhaldet. Det tyder på at arbeidet med lokal plan i seg sjølv kan vera ein reiskap for bevisstgjering av medarbeidarane. I den grad trusopplæringa klarer denne vektleggjinga av det kristne innhaldet, ligg det til rette for at ein utviklar ein viktig dimensjon ved det å vera menighet.

Elisabeth Tveito Johnsen argumenterer i ein artikkel for at det som ikkje er særeigne kyrkjelege praksisar, bør vera ein konstituerande del av innhaldet $\mathrm{i}$ trusopplæringstiltaka. Ho kritiserer teologien i trusopplæringa for å ha vore ein autoritativ diskurs, ein totalpakke som ein anten kan godta eller avvisa. Johnsen viser på ein overtydande måte korleis særleg den såkalla gjennomføringsfasen i 
reforma har vektlagt Bibel, bøn og gudsteneste, og tydeleggjer korleis verkt $\varnothing y e t$ for utvikling av lokale planar sikrar at det teologiske innhaldet blir synleggjort i planane. Dette meiner ho kan ha ført til at trusopplæringa blir skilt frå det barn og unge elles driv med. Hennar bidrag er «å åpne for at teologi ikke er et system som skal overføres, men biter og deler som kan brukes, blandes, omformes og stadig reformuleres ». (Johnsen 2015:143). At våre informantar så sterkt understrekar trua på Gud som viktig i trusopplæringa, treng ikkje bety at dei ikkje òg ser andre element som ein del av tiltaka. Det verkar likevel som informantane, ut frå det dei uttrykkjer i intervjua, meiner at det er det spesifikt teologiske innhaldet som er konstituerande, og dei prøver å verkeleggjera dette i praksis så godt som mogleg. Her synest det traderte teologiske innhaldet i Bibelen og den kristne tradisjonen å spela ei avgjerande rolle.

Det ser ut til å vera ein ambivalens i materialet når det gjeld tilhøvet mellom trusopplæringa og andre delar av verksemda i menigheten. Særleg kjem dette til syne i det som kan seiast å vera dei mest overlappande kontaktflatene, forholdet til anna barne- og ungdomsarbeid og til gudstenesta. Spenninga som finst mellom tidsavgrensa og kontinuerlege tiltak er tidlegare dokumentert. I rapporten om profesjonalisering og frivillighet er det særleg representantar for dei frivillige organisasjonane som peikar på dette (Aagedal, Haakedal, og Kinserdal 2014:54, 61). I vårt materiale finn me denne spenninga mellom dei som arbeider i same menigheten. I hovudsak er alle informantane samde om at gudstenesta òg skal femna trusopplæringstiltak, men det er likevel ei spenning mellom forskjellige brukargrupper i gudstenesta.

Det er òg tankevekkande at det finst stemmer både i sokneråd og mellom prestane som seier at det er vanskeleg å ha eit auge for og oversikt over heilskapen $\mathrm{i}$ menigheten. Kanskje det kan tyda på at ein menighet er ein såpass uoversiktleg organisasjon at det trengst ei ennå tydelegare leiing enn tilfellet er i dag for at ei utvikling i ønska retning kan bli målretta. Samla sett tolkar me dimensjonen «med deltaking» som til dels spenningsfull. For at trusopplæringa kan bli ein ennå viktigare faktor i utvikling av menigheten trengs det ei klarare styring av alle verksemder i menigheten mot felles mål.

Kva skal me så svara på det innleiande spørsmålet vårt: Korleis kan trusopplæringa vera ein faktor i å utvikla menighetene i Den norske kyrkja? ${ }^{15} \mathrm{Ut}$ frå det teologiske perspektivet me har lagt til grunn i artikkelen, ser me at trusopplæringa har eit potensiale for utvikling av menigheten som heilskap. Det er likevel ein fare for at trusopplæringa kan bli isolert til ein aktivitet, og at fokus blir for mykje innover. Det er fleire av dei ekklesiologiske dimensjonane trusopplæringa ikkje synest å bidra til å utvikla. Me ser eit potensiale for meir heilskapleg

15 Det viste seg at det ikkje var mogleg å sjå noko spesiell utvikling frå intervju 1 til intervju 2, slik me hadde sett føre oss i utgangspunktet. Kanskje det kan tyda på at arbeidet med lokal plan ikkje har ført til påviselege endringar i dei intervjua sine oppfatningar? 
menighetsutvikling ved å vera mindre opptatt av eiga utvikling og meir fokusert på kva som er menigheten sitt oppdrag som sendt til verda ( «i verda»). Her kan trusopplæringa la seg utfordra av det fleirkulturelle og fleirreligiøse samfunnet, impulsar frå den verdsvide kyrkja og av dei udøypte i nærmiljøet. Vilje til endring og stadig å vera i utvikling for å tena barn og unge på betre måtar («i rørsle»), både i den lokale konteksten og i vidare sirklar, kan òg bidra til både ei betre trusopplæring og til utvikling av menigheten som heilskap. Trusopplæringa har alt påverka menighetene og kjem til å gjera det vidare. Utfordringa er, slik me ser det, at trusopplæringa blir ein integrert del av eit målretta arbeid for å setja menigheten betre i stand til å vera det den er kalla til å vera og gjera det den er kalla til å gjera.

\section{LitTERATUR}

Aagedal, Olaf, Elisabet Haakedal og Frode Kinserdal. 2014. Profesjonalisering og frivillighet. Trosoppleeringsreformen og samarbeid mellom Den norske kirke og de kristne organisasjonene. Vol. 2014:1, KIFO rapport (trykt utg.). Oslo: Stiftelsen Kirkeforskning.

Austnaberg, Hans. 2017. «Alle st $ø$ ttar trusopplæringa. Tverrfagleg samarbeid mellom prestar og undervisningstilsette i utvikling av trusopplæringa.» I Prismet 68 (3) S. 211-229

Austnaberg, Hans, Erling Birkedal og Heid Leganger-Krogstad. 2017. «Kirkelig undervisning - hva nå? Utfordringer med religionsmangfold og lav deltakelse.» I Prismet 68 (3) s. 259-274

Birkedal, Erling. 2015. «Menighetsutvikling i et folkekirkeperspektiv. Hvorfor og hvordan drive systematisk utviklingsarbeid i Den norske kirke.» I Folkekirke nå, redigert av Stephanie Dietrich, Hallgeir Elstad, Beate Fagerli og Vidar L. Haanes, s. 155-165. Oslo: Verbum.

Birkedal, Erling. 2017. «Frivillighet i trosopplæringen. En refleksjon om samspill mellom ansatte og frivillige.» I Prismet 68 (3) s. 231-241.

Birkedal, Erling og Hans Austnaberg. 2017. «Planarbeid i trosopplæring som ressurs for menigheten?» I Prismet 68 (3) s. 189-209

Birkedal, Erling, Heid Leganger-Krogstad og Hans Austnaberg. 2017. «Kirkelig undervisning - hva nå? Utfordringer med religionsmangfold og lav deltakelse.» I Prismet 68 (3) s. 259-274

Hammersley, Martyn, and Paul Atkinson. 2007. Ethnography: principles in practice. 3rd ed. London: Routledge.

Hegstad, Harald. 2009. Den virkelige kirke: bidrag til ekklesiologien. Vol. nr. 19. s. 9-27 Trondheim: Tapir Akademisk Forlag.

Hegstad, Harald. 2011. «Hva er vi kalt til å være og hva er vi kalt til å gjøre? Fem dimensjoner ved å være menighet.» I Sammen i forandring. Refleksjoner om menig- 
hetsutvikling i folkekirken, redigert av Erling Birkedal, Harald Hegstad og Turid Skorpe Lannem, s. 9-27. Oslo: IKO-Forlaget.

Hegstad, Harald. 2012. «Menighetsutvikling i folkekirken. Grunnlag og formål.» I Menighetsutvikling i folkekirken. Erfaringer og muligheter, redigert av Erling Birkedal, Harald Hegstad og Turid Skorpe Lannem, 9-23. Oslo: IKO-Forlaget.

Hegstad, Harald, Olaf Aagedal og Anne Schanche Selbekk. 2008. Når tro skal læres: sju fortellinger om lokal trosopplcering. Trondheim: Tapir Akademisk Forlag.

Horsfjord, Helene, Torgeir Sørensen, Gunnar Heiene, Heid Leganger-Krogstad og Morten Holmqvist. 2015. Kompetanse, utdanning og motivasjon: en kartlegging av undervisningstjenesten i Den norske kirke. MF-rapport 1:2015. Oslo: Det teologiske menighetsfakultet.

Høeg, Ida Marie, og Ann Kristin Gresaker. 2015. Når det rokkes ved tradisjon og tilhørighet. Nedgang i oppslutning om dåp i Oslo bispedømme. Vol. 2015:2, KIFO rapport (trykt utg.). Oslo: KIFO, Institutt for kirke-, religions- og livssynsforskning.

Johnsen, Elisabeth Tveito. 2015. «Teologi som ulike biter og deler. Ti år med trosopplæring i Den norske kirke.» Prismet 66 (3) s.125-144.

Kirkerådet. 2010. Gud gir - vi deler. Plan for trosopplering i Den norske kirke. Oslo: Den norske kirke.

Kvale, Steinar. 1996. InterViews. An Introduction to Qualitative Research Interviewing. Thousand Oaks, CA, London, New Delhi: SAGE.

Leganger-Krogstad, Heid. 2017. "Trosopplæring og gudstjenester. Menighetsutvikling i dybde og bredde." Prismet 68 (3) s. 243-258

Swinton, John, and Harriet Mowat. 2016. Practical theology and qualitative research. 2nd ed. London: SCM Press. 